\title{
IMPLEMENTASI FATWA DSN-MUI PADA PRODUK ARRUM HAJI DI PEGADAIAN SYARIAH CABANG BABAKAN SURABAYA ${ }^{1}$
}

\author{
Aulia Nabila Luthfina \\ Departemen Ekonomi Syariah, Fakultas Ekonomi dan Bisnis, Universitas Airlangga \\ Email: aulia.nabila.Iuthfina-2015@feb.unair.ac.id
}

\section{A. Syifaul Qulub}

Departemen Ekonomi Syariah, Fakultas Ekonomi dan Bisnis, Universitas Airlangga Email: a-syifaul-q@feb.unair.ac.id

\begin{abstract}
:
Arrum Haji products are one of the product innovations developed by Sharia Pawnshops precisely in 2016 after the banning of hajj bailout products offered by Islamic banking. In its development, Arrum Haji products cannot be separated from obstacles. One of them is that not many people know the whole product of Arrum Hajj and sharia whether or not the product. So that this study will explain the entire Arrum Haji product and review its Islamic compliance based on the provisions of the DSN-MUI Fatwa. This study uses qualitative methods with descriptive case study strategies. The object of this study is the Babakan Surabaya Islamic pawnshop. Data retrieval is done by interviewing 4 informants consisting of 3 sharia pawnshops staff Babakan Surabaya and General Secretary of the DSN-MUI in East Java. Interpretation and conclusions are made by linking between data obtained in interviews and documentation. The results showed that the Arrum Haji product was an innovation for hajj bailout products whose operations had followed the provisions of the DSNMUI fatwa. Arrum Haji products are not the same as hajj bailout products, because both have different ujrah systems.
\end{abstract}

\section{Keywords: Shari'a Pawnshop, Arrum Haji Products, Sharia Compliant, DSN-MUI}

\section{PENDAHULUAN}

Pegadaian merupakan salah satu bentuk lembaga keuangan non-bank di Indonesia yang secara resmi dan berdasarkan hukum mempunyai izin untuk melaksanakan kegiatan pembiayaan dalam bentuk penyaluran kredit atas dasar hukum gadai dan didirikan untuk membantu program pemerintah dalam rangka meningkatkan kesejahteraan rakyat Indonesia. Lembaga pegadaian didirikan pula untuk menjadi sebuah lembaga yang membantu berbagai lapisan masyarakat yang membutuhkan solusi pendanaan. Lembaga pegadaian hadir dengan memberikan fasilitas pinjaman vang dengan sistem yang mudah. Sehingga dengan kemudahan yang ditawarkan tersebut, diharapkan dapat membantu masyarakat dalam hal pendanaan, mencegah timbulnya rentenir, praktik gadai gelap serta mencegah pinjaman-pinjaman tidak wajar lainnya yang bersifat mempersulit masyarakat.

Seiring perkembangan zaman, permintaan atas produk-produk kevangan berbasis syariah semakin meningkat. Salah satu faktornya dikarenakan masyarakat di Negara Indonesia yang mayoritas beragama Islam sehingga kesadaran mengenai riba,

\footnotetext{
${ }^{1}$ Jurnal ini merupakan bagian dari skripsi dari Aulia Nabila Luthfina, NIM: 041511433041, yang diuji pada 19 Juli 2019.
} 
gharar, maysir, dhulm, dan haram khususnya pada produk keuangan cukup tinggi. Hal tersebut berlaku pula pada permintaan atas produk gadai yang sesuai dengan prinsip syariah. Praktik gadai syariah (rahn) dijalankan dengan landasan dari beberapa dalil dalam AlQur'an maupun Hadits. Salah satunya pada firman Allah SWT dalam Q.S AlBaqarah ayat 283.

Untuk memenuhi kebutuhan masyarakat akan praktik gadai yang berprinsip syariah, pada tahun 2002 lembaga pegadaian bekerja sama dengan Bank Muamalat Indonesia (BMI) untuk membentuk Unit Layanan Gadai Syariah (ULGS) dari lembaga pegadaian yaitu Pegadaian Syariah. Sampai saat ini, pegadaian syariah semakin berkembang pesat dan mendapatkan sambutan positif dari masyarakat. Perkembangan pegadaian syariah tentunya tidak lepas pula dari perkembangan produk-produk gadai syariah yang diciptakan untuk memberikan kemudahan bagi masyarakat. Terdapat 3 (tiga) kategori produk pada pegadaian syariah yaitu kategori produk pembiayaan, kategori produk emas dan kategori produk jasa/pelayanan.

Salah satu produk yang cukup baru dikembangkan oleh pegadaian syariah adalah produk Arrum Haji. Produk tersebut berbentuk pembiayaan yang bertujuan untuk pemenuhan biaya setoran awal haji. Latar belakang dikembangkannya produk Arrum Haji dikarenakan adanya permasalahan pada produk dana talangan haji yang ditawarkan perbankan syariah. Implementasi dana talangan haji pada sebagian besar perbankan syariah tidak sesuai dengan ketentuan dalam fatwa DSN-MUI, ketidaksesuaian tersebut terletak pada sistem ujrah. Ujrah dalam dana talangan haji ditentukan berdasarkan besarnya dana yang dipinjam. Berdasarkan adanya permasalahan tersebut, kemudian Kementrian Agama mengeluarkan Peraturan Menteri Agama (PMA) Nomor 24 Tahun 2016 sebagai bentuk larangan tertulis bagi perbankan syariah sebagai Bank Penerima Setoran BPIH untuk menawarkan produk dana talangan haji. Kemudian, atas dasar hal tersebut pegadaian syariah meluncurkan produk Arrum Haji pada pertengahan tahun 2016 sebagai solusi alternatif bentuk talangan haji yang sesuai dengan prinsip syariah.

Dalam produk Arrum Haji terdapat biaya mu'nah atau biaya pemeliharaan jaminan (emas) yang harus dibayarkan oleh nasabah Arrum Haji. Pada poin inilah yang juga menjadi permasalahan. Dengan adanya biaya mu'nah sebagian masyarakat berpendapat bahwa produk Arrum Haji tidak berbeda dengan dana talangan haji pada umumnya dan beranggapan bahwa kedua produk tersebut memiliki prosedur yang sama yaitu meminjamkan sejumlah dana talangan untuk biaya setoran awal ibadah haji dan keduanya diikuti dengan 
Luthfina, et al/Jurnal Ekonomi Syariah Teori dan Terapan Vol. 6 No. 12 Desember 2019: 2568-2580; IMPLEMENTASI FATWA DSN-MUI PADA PRODUK ARRUM HAJI DI PEGADAIAN SYARIAH CABANG BABAKAN SURABAYA

tambahan biaya yang ditentukan berdasarkan pinjaman. Permasalahan tersebut kemudian menimbulkan pertanyaan mengenai syariah tidaknya produk Arrum Haji, sehingga menjadi kendala dalam perkembangan produk Arrum Haji. Selain itu, beberapa kendala lainnya yaitu sebagian besar masyarakat belum mengenal dan memahami produk Arrum Haji khususnya mengenai prosedurnya serta masih adanya citra bahwa pegadaian syariah tidak berbeda dengan pegadaian konvensional.

Berdasarkan uraian di atas, keseluruhan mengenai produk Arrum Haji perlu dikaji kembali terkait dengan komponen-komponen terkait akadnya, keseluruhan prosedur mulai dari prosedur pengajuan pembiayaan Arrum Haji, prosedur perhitungan angsuran termasuk perhitungan biaya administrasi dan biaya mu'nah (biaya pemeliharaan jaminan) sampai pada prosedur ketika terjadi wanprestasi nasabah. Produk Arrum Haji tidak hanya dikaji kembali secara rinci tetapi juga perlu ditinjau kesesuaian syariahnya berdasarkan fatwa DSN-MUI yang menjadi landasan. Sehingga penulis tertarik untuk mencari tahu bagaimana keseluruhan prosedur dalam produk Arrum Haji serta apakah telah sesuai dengan syariah yang ditinjau dari ketentuan Fatwa DSN-MUI atau belum.

\section{TINJAUAN PUSTAKA}

\section{Sistem Kevangan Syariah}

Sistem keuangan syariah merupakan sistem keuangan yang berfungsi sebagai lembaga perantara antara pihak yang membutuhkan dana dengan pihak yang memiliki kelebihan dana melalui produk dan jasa keuangan yang dijalankan sesuai dengan prinsipprinsip syariah berdasar pada Al-Qur'an dan As-Sunnah. Dalam sistem keuangan syariah, seluruh transaksi yang dilakukan harus dilaksanakan dengan menerapkan kombinasi dua prinsip yaitu prinsip syar'i yang diambil dari ajaran Al-Qur'an dan As-Sunnah serta prinsip tabi'i yang berasal dari hasil interpretasi akal manusia khususnya dalam bidang ekonomi

\section{Lembaga Keuangan Syariah}

Lembaga Kevangan Syariah (LKS) merupakan sebuah lembaga keuangan yang mengeluarkan produk-produk keuangan syariah dan lembaga yang mendapat izin operasional sebagai lembaga keuangan syariah. Ciri khas dari LKS yaitu adanya penghapusan sistem bunga dan mendorong sistem bagi hasil, manajemen operasionalnya didasarkan pada muamalah islamiah (perilaku dan praktik islami) serta tidak menerapkan kegiatan-kegiatan yang bertentangan dengan syariat Islam. Dalam perkembangannya, lembaga keuangan di Indonesia dikenal dengan dua jenis yaitu lembaga keuangan bank dan nonbank. Lembaga keuangan bank terdiri dari Bank Umum Syariah (BUS) dan Bank Pembiayaan Rakyat Syariah (BPRS). Sedangkan lembaga keuangan non-bank terdiri Asuransi Syariah, Baitul Mal wa 
Luthfina, et al/Jurnal Ekonomi Syariah Teori dan Terapan Vol. 6 No. 12 Desember 2019: 2568-2580; IMPLEMENTASI FATWA DSN-MUI PADA PRODUK ARRUM HAJI DI PEGADAIAN SYARIAH CABANG BABAKAN SURABAYA

Tamwil (BMT), Koperasi Syariah dan Pegadaian Syariah.

\section{Pegadaian Syariah}

Pegadaian syariah merupakan unit syariah dari perusahaan pegadaian yang merupakan hasil kerjasama dengan Bank Muamalat Indonesia (BMI). Pegadaian syariah menjalankan operasionalnya berdasarkan acuan sistem administrasi modern yang mengutamakan asas rasionalitas, efisiensi dan efektifitas yang kemudian dijalankan sesuai dengan nilainilai syariah.

\section{Produk Arrum Haji}

Produk Arrum Haji merupakan salah satu produk yang dikembangkan oleh pegadaian syariah. Produk ini mulai dikembangkan pada tahun 2016 dengan tujuan untuk memberikan kemudahan bagi masyarakat yang ingin menunaikan ibadah haji tetapi kesulitan untuk melengkapi setoran awal BPIH dalam rangka memperoleh nomor porsi haji. Produk Arrum Haji dikembangkan atas dasar adanya ketidaksesuaian produk dana talangan haji pada perbankan syariah dengan ketentuan-ketentuan dalam fatwa DSN-MUI.

\section{Produk Dana Talangan Haji}

Produk dana talangan haji merupakan salah satu bentuk produk pembiayaan yang ditawarkan oleh perbankan syariah kepada masyarakat. Produk ini diperuntukkan untuk memberikan kemudahan bagi masyarakat muslim yang ingin menunaikan ibadah haji namun kesulitan dalam memenuhi biayanya. Dalam dana talangan haji, pihak LKS yaitu perbankan syariah memberikan pinjaman sejumlah dana kepada nasabah dan mensyaratkan ujrah atas pengurusan perolehan porsi haji. Pihak LKS diperbolehkan mengenakan ujrah atas pembiayaan namun besaran ujrah tidak boleh didasarkan pada jumlah pembiayaan. Namun dana talangan haji yang ditawarkan beberapa bank syariah diketahui tidak memenuhi ketentuan tersebut.

\section{Wanprestasi Akad}

Dalam pandangan ekonomi syariah, wanprestasi yaitu bilamana dalam sebuah akad yang telah secara sah menurut ketentuan hukum tidak dilaksanakan sebagaimana mestinya sehingga terjadi kesalahan pada pihak debitur. Atas beberapa bentuk wanprestasi tersebut, lembaga keuangan syariah memberlakukan dua bentuk sanksi yang dikenakan kepada debitur yang melakukan wanprestasi, yaitu ta'zir (denda keterlambatan) dan ta'widh (ganti rugi).

\section{Kesesuaian Syariah}

Kesesuaian syariah merupakan salah satu faktor penting yang harus diperhatikan oleh setiap lembaga kevangan syariah. Adanya kesesuaian syariah dianggap sebagai wujud dari pemenuhan prinsip-prinsip syariah dan menjadi wujud intergritas serta kredibilitas dari lembaga keuangan syariah. 


\section{METODE PENELITIAN}

Penelitian ini menggunakan metode kualitatif dengan strategi studi kasus secara deskriptif. Teknik pengumpulan data melalui wawancara kepada 4 responden yang terdiri dari 3 staff pegadaian syariah Babakan Surabaya dan Sekretaris Umum DSN-MUI wilayah Jawa Timur. Objek dari penelitian ini adalah Pegadaian Syariah Cabang Babakan Surabaya. Analisis data dilakukan pendekatan analisis data kualitatif. Interpretasi dan pengambilan kesimpulan dilakukan dengan menghubungkan antar data yang diperoleh dalam wawancara dan dokumentasi

\section{HASIL DAN PEMBAHASAN}

\section{Produk Dana Talangan Haji}

Berdasarkan hasil wawancara, poin-poin yang didapatkan yaitu mengenai: (1) pelarangan perbankan syariah untuk menawarkan produk dana talangan haji, (2) kebolehan menunaikan ibadah haji menggunakan dana talangan atau pinjaman dan (3) konsep istatha'a dalam ibadah haji.

Pertama, pada dasarnya produk dana talangan haji sebenarnya tidak dilarang. Namun, beberapa dari perbankan syariah yang menawarkan produk dana talangan haji diketahui mengenakan ujrah atau upah yang besarnya ditentukan berdasarkan jumlah pinjaman. Hal tersebut yang kemudian menjadi substansi pelarangan dana talangan haji karena system ujrah yang seperti itu tidak sesuai dengan ketentuan dalam fatwa DSN-MUI Nomor:29//DSN$\mathrm{MUI} / \mathrm{VI} / 2002$ tentang Pembiayaan Pengurusan Haji Lembaga Keuangan Syariah.

Kedua, hal yang juga menjadi permasalahan adalah mengenai kebolehan menunaikan ibadah haji dengan dana talangan atau dana pinjaman. Sebagian besar masyarakat berpendapat bahwa istilah dana talangan atau dana pinjaman yang diperuntukkan untuk mendaftar haji sama dengan ibadah haji melalui jalan berhutang dan tidak sah hukumnya karena tidak sesuai dengan konsep istatha'a atau mampu sebagaimana disebutkan dalam Q.S Al-Imron ayat 97. Namun menurut Majelis Ulama Indonesia (MUI), hal tersebut tidak dibenarkan karena sebenarnya tidak ada dalil yang melarang perginya seseorang untuk menunaikan ibadah haji dengan jalan berhutang serta tidak menyalahi konsep istatha'a.

Ketiga, sebagian besar masyarakat belum memahami arti sebenarnya dari konsep istatha'a atau mampu dalam hal ibadah haji. Menurut Bapak Ainul Yaqin, konsep istatha'a atau mampu dalam ibadah haji dibagi menjadi dalam tiga kategori, yaitu:

1. Istatha'a atau mampu dalam segi kesehatan, hal ini mengartikan bahwa sejauh mana kesiapan seseorang dari sisi kesehatan 
2. Istatha'a atau mampu dalam segi biaya, hal ini melihat apakah seorang calon jama'ah haji benar-benar mampu memenuhi biaya yang diperlukan dalam keseluruhan proses ibadah haji.

3. Istatha'a atau mampu dalam segi waktu. Saat ini, waktu tunggu keberangkatan haji terhitung lama (sekitar 10-20 tahun). Sehingga mampu dalam segi waktu berarti apakah seorang calon jama'ah haji akan mampu melaksanakan ibadah haji dengan waiting list yang cukup panjang.

\section{Produk Arrum Haji}

Berdasarkan hasil wawancara, produk Arrum Haji merupakan salah satu produk yang dikembangkan oleh pegadaian syariah. Produk Arrum Haji merupakan inovasi produk dana talangan haji yang dijalankan dengan memenuhi prinsip-prinsip syariah. Akad utama yang digunakan dalam produk ini yaitu akad rahn yang timbul karena adanya akad utang piutang (qardh). Selain itu juga terdapat akad kafalah. Adanya akad kafalah bertujuan untuk mengurangi tingkat resiko kredit macet dari skim pembiayaan produk Arrum Haji.

\section{Dalam perkembangannya}

terdapat beberapa permasalahan atau kendala lain yang dihadapi pegadaian syariah Babakan Surabaya dalam mengembangkan produk Arrum Haji. Kendala-kendalanya yaitu: (1) Jumlah nasabahnya jika dilihat perbulan mengalami penurunan, tetapi pihak pegadaian syariah tetap mengusahakan agar jumlah nasabah Arrum Haji dapat meningkat dengan cara persuasif kepada nasabah. (2) Belum banyak masyarakat yang mengetahui produk Arrum Haji dan prosedurnya (3) Masin terdapat masyarakat yang menganggap bahwa sistem biaya mu'nah tidak berbeda dengan tambahan biaya (ujrah) produk dana talangan haji yang ada pada perbankan Syariah, sehingga syariah tidaknya produk masih diragukan.

Untuk menjawab beberapa kendala tersebut, berikut ini penjelasan keseluruhan prosedur pengajuan produk Arrum Haji dan prosedur perhitungan angsurannya. Ketika mengajukan pembiayaan Arrum Haji beberapa persyaratan yang harus dipenuhi oleh nasabah Arrum Haji antara lain yaitu:

1. Mengisi formulir produk Arrum Haji dan menandatanganinya

2. Menyerahkan photocopy KTP, Kartu Keluarga (KK), buku nikah (jika ada)

3. Menyerahkan jaminan (marhun) berupa emas: Peraturan sebelumnya yaitu emas yang dijadikan sebagai jaminan harus sekitar 15 gram atau setara dengan Rp 7.000.000. Namun mulai awal tahun 2019, peraturan mengenai besarnya jaminan emas diubah. Nasabah dapat menyerahkan jaminan minimal emas seberat 3 gram atau setara dengan sekitar Rp 1.900.000. 
4. Membayar biaya administrasi sebesar Rp 270.000, setoran tabungan haji sebesar Rp 500.000 dan biaya asuransi untuk jaminan (imbal jasa kafalah).

5. Membayar angsuran pembiayaan disertai dengan biaya pemeliharaan jaminan (mu'nah) setiap bulan

6. Memenuhi persyaratan untuk mendaftar haji yang tentukan oleh Kementrian Agama

Alur pengajuan pembiayaan Arrum Haji Pegadaian Syariah dapat dijelaskan melalui skema dibawah ini:

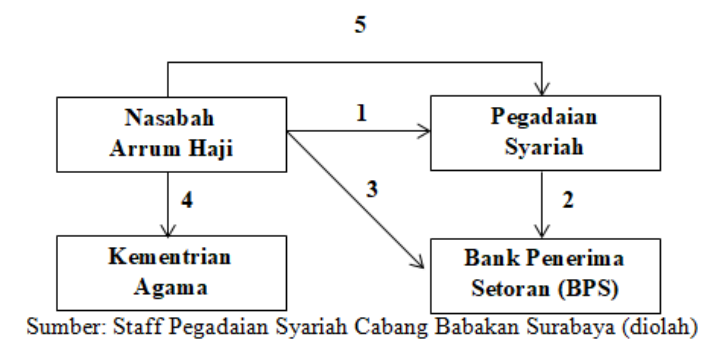

\section{Gambar 1.}

\section{Alur Pengajuan pada Produk Arrum Haji}

Simulasi Perhitungan Angsuran Produk Arrum Haji

Sebelum pada perhitungan angsuran, berikut ini merupakan rincian biaya awal akad pada produk Arrum Haji di Pegadaian Syariah yang harus dibayarkan nasabah ketika mendaftar produk Arrum Haji:

Tabel 1.

\section{Biaya pada saat awal akad}

\begin{tabular}{|c|c|c|c|c|c|}
\hline No. & Lama Angsuran & $\begin{array}{c}\text { Biaya } \\
\text { Administrasi }\end{array}$ & $\begin{array}{l}\text { Setoran Awal } \\
\text { Tabungan }\end{array}$ & $\begin{array}{l}\text { Imbal Jasa } \\
\text { Kafalah }\end{array}$ & $\begin{array}{c}\text { TOTAL } \\
\text { Biaya Awal }\end{array}$ \\
\hline 1. & 1 Tahun (12 Bulan) & Rp 270.000 & Rp 500.000 & Rp 70.000 & Rp 840.000 \\
\hline 2. & 2 Tahun (24 Bulan) & Rp 270.000 & Rp 500.000 & Rp 112.500 & Rp 882.500 \\
\hline 3. & 3 Tahun (36 Bulan) & Rp 270.000 & Rp 500.000 & Rp 175.000 & Rp 945.000 \\
\hline 4. & 4 Tahun (48 Bulan) & Rp 270.000 & Rp 500.000 & Rp 256.000 & Rp 1.035.000 \\
\hline 5. & 5 Tahun (60 Bulan) & Rp 270.000 & Rp 500.000 & Rp 412.500 & Rp 1.182.500 \\
\hline
\end{tabular}

Sumber: Pegadaian Syariah Babakan Surabaya

Untuk simulasi atau contoh angsuran dan besarnya biaya mu'nah akan dijelaskan berikut ini:

a. Taksiran marhun: Rp 4.500.000

b. Angsuran pokok: Rp 25.000.000 / Bulan angsuran

c. Biaya mu'nah: 0,95\% $\times$ Taksiran marhun.

d. $0,95 \% \times \operatorname{Rp} 4.500 .000=\operatorname{Rp} 42.750$

Sehingga biaya mu'nah atau biaya pemeliharaan jaminan yang harus dibayarkan oleh nasabah sebesar Rp 42.750 pada setiap pembayaran angsuran. Angka tersebut sama pada tiap jangka waktu pembayaran yaitu 12-60 bulan. Penjelasan mengenai simulasi angsuran produk Arrum Haji terdapat pada tabel berikut ini:

Tabel 2.

\section{Simulasi Angsuran Produk Arrum Haji}

\begin{tabular}{|l|l|l|l|l|}
\hline No. & \multicolumn{1}{|c|}{ Lama Angsuran } & $\begin{array}{c}\text { Angsuran } \\
\text { Pokok }\end{array}$ & \multicolumn{1}{c|}{$\begin{array}{c}\text { Biaya } \\
\text { Mu'nah }\end{array}$} & $\begin{array}{c}\text { Total Angsuran (Per } \\
\text { bulan) = Angsuran } \\
\text { pokok + Biaya Mu'nah }\end{array}$ \\
\hline 1. & 1 Tahun (12 Bulan) & $\mathrm{Rp} \mathrm{2.083.333}$ & $\mathrm{Rp} \mathrm{42.750}$ & $\mathrm{Rp} \mathrm{2.126.083}$ \\
\hline 2. & 2 Tahun (24 Bulan) & $\mathrm{Rp} \mathrm{1.041.667}$ & $\mathrm{Rp} \mathrm{42.750}$ & $\mathrm{Rp} \mathrm{1.084.417}$ \\
\hline 3. & 3 Tahun (36 Bulan) & $\mathrm{Rp} \mathrm{694.445}$ & $\mathrm{Rp} \mathrm{42.750}$ & $\mathrm{Rp} \mathrm{737.195}$ \\
\hline 4. & 4 Tahun (48 Bulan) & $\mathrm{Rp} \mathrm{520.833}$ & $\mathrm{Rp} \mathrm{42.750}$ & $\mathrm{Rp} \mathrm{563.583}$ \\
\hline 5. & 5 Tahun (60 Bulan) & $\mathrm{Rp} \mathrm{416.667}$ & $\mathrm{Rp} \mathrm{42.750}$ & $\mathrm{Rp} \mathrm{459.417}$ \\
\hline
\end{tabular}

Sumber: Pegadaian Syariah Babakan Surabaya

Perbedaan Produk Arrum Haji dan Produk Dana Talangan Haji 
Tabel 3.

Perbedaan Arrum Haji dan Dana Talangan

Haji

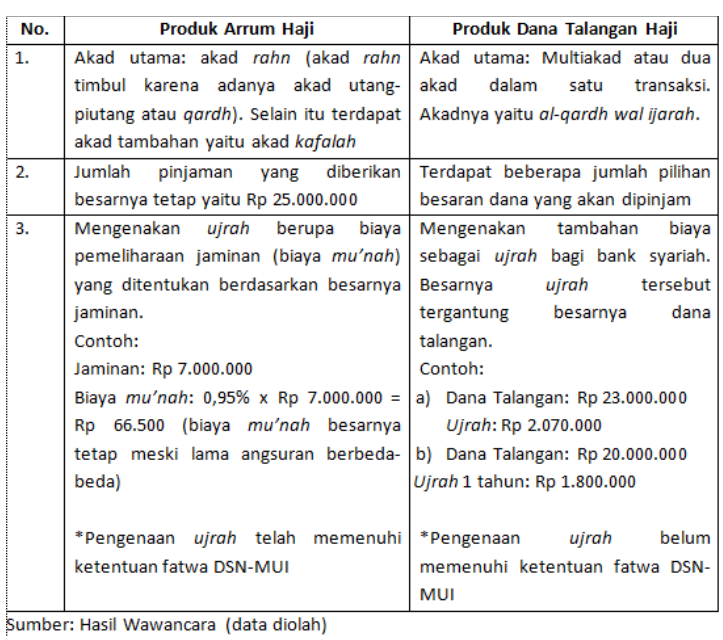

Analisis Kesesuaian Syariah Produk Arrum

Haji dengan Fatwa DSN-MUI

1. Fatwa DSN-MUI Nomor:92/DSNMUI/IV/2014 tentang Pembiayaan yang Disertai Rahn (At-Tamwil Al-Mautsuq Bi

\section{Al-Rahn)}

Dalam fatwa ini, poin-poin penting yang dijelaskan yaitu mengenai ketentuan hukum, ketentuan terkait jaminan (marhun), ketentuan terkait utang (marhun bih), ketentuan terkait akad, ketentuan terkait pendapatan murtahin dan ketentuan penyelesaian akad.

Terkait dengan ketentuan hukum, disebutkan dalam fatwa bahwa pada dasarnya segala bentuk penyaluran dana yang dilakukan oleh LKS diperbolehkan menyertakan jaminan. Jaminan disertakan dalam pembiayaan dengan tujuan untuk memperkuat akad dan pihak-pihak yang berakad dapat saling percaya.
Selanjutnya yaitu ketentuan terkait jaminan (marhun). Beberapa ketentuan mengenai marhun diantaranya yaitu harus berupa harta berharga baik benda bergerak maupun tidak bergerak dan yang dapat diperjual-belikan, marhun yang kepemilikannya musya' harus digadaikan sesuai porsi kepemilikan dan marhun boleh diasuransikan.Dalam produk Arrum Haji marhun yang disertakan yaitu berupa emas atau logam mulia. Marhun yang disertakan tersebut haruslah milik sendiri dan boleh diasuransikan. Pada awal akad dalam produk Arrum Haji nasabah diwajibkan membayar imbal jasa kafalah yang juga disebut sebagai biaya asuransi jaminan. Sehingga terkait ketentuan hokum dan jaminan (marhun) pada produk Arrum Haji telah memenuhi ketentuan fatwa DSN-MUI.

Kemudian mengenai ketentuan terkait utang (marhun bih). Beberapa ketentuan marhun bih dalam fatwa ini diantaranya yaitu marhun bih boleh dalam bentuk uang atau barang, marhun bih bersifat mengikat, marhun bih harus jelas jumlahnya dan marhun bih tidak boleh bertambah jika waktu pembayaran diperpanjang serta ketika waktu pembayaran diperpanjang LKS boleh mengenakan denda. Dalam produk Arrum Haji, pembiayaan atau dengan kata lain utang yang diberikan pegadaian syariah yaitu dalam bentuk vang dan jelas jumlahnya yaitu sebesar 
Rp 25.000.000, pembiayaan tersebut bersifat mengikat karena hanya akan selesai ketika nasabah melunasi seluruh Utangnya, dan ketika nasabah memerlukan perpanjangan waktu pembayaran, utang nasabah tidak akan bertambah karena pegadaian syariah tidak menerapkan sistem bunga (riba). Atas adanya keterlambatan pembayaran kewajiban, pegadaian syariah hanya mengenakan denda sebesar $4 \%$ atas keterlambatan waktu pembayaran.

Selanjutnya yaitu mengenai ketentuan terkait akad. Dalam fatwa ini, dipaparkan bahwa akad rahn dibolehkan hanya karena tiga hal yaitu karena adanya utang-piutang (qardh), jual beli tidak tunai dan akad ijarah. Produk Arrum Haji termasuk pada akad rahn yang timbul karena utang-piutang (qardh). Sehingga ketentuan terkait dengan akad pada produk Arrum Haji telah sesuai dengan fatwa.

Kemudian mengenai ketentuan pendapatan murtahin. Dalam fatwa dijelaskan bahwa pendapatan atau ujrah bagi murtahin dalam akad rahn yang timbul karena utang-piutang berasal dari biaya mu'nah atau biaya pemeliharaan jaminan. Ujrah atau pendapatan yang diperoleh pihak pegadaian syariah yaitu berasal dari biaya mu'nah atau biaya pemeliharaan jaminan milik nasabah yang besarnya ditentukan pada saat awal akad, besar biaya mu'nah yang ditentukan yaitu sebesar $0,95 \%$ dari nilai taksiran jaminan nasabah. Sehingga ketentuan terkait pendapatan murtahin pada produk Arrum Haji telah sesuai dengan fatwa.

Ketentuan yang terakhir yaitu terkait dengan penyelesaian akad rahn. Dalam fatwa dijelaskan beberapa ketentuan terkait penyelesaian akad rahn, diantaranya yaitu: 1) akad rahn akan berakhir ketika nasabah sudah melunasi seluruh kewajibannya dan murtahin mengembalikan marhun. 2) ketika nasabah tidak melaksanakan kewajibannya maka murtahin wajib mengingatkan. 3) namun apabila nasabah tidak lagi mampu melunasi kewajibannya maka LKS diperbolehkan menjual jaminan sebagai pengganti kewajiban nasabah. Peraturan dalam penjualan jaminan yaitu jika harga jaminan diatas utang maka kelebihannya dikembalikan ke nasabah. Jika harga jaminan dibawah utang maka kekurangannya tetap menjadi tanggung jawab nasabah. Menyambung pada ketentuan selanjutnya yaitu apabila terdapat pihak yang tidak menunaikan kewajibannya atau jika terjadi perselisihan diantara para pihak, maka penyelesaiannya dilakukan melalui lembaga penyelesaian sengketa berdasarkan syariah setelah tidak tercapai kesepakatan melalui musyawarah. 
Dalam produk Arrum Haji langkah utama yang dilakukan pihak pegadaian syariah ketika nasabah tidak melunasi kewajibannya yaitu dengan mengingatkan nasabah melalui telepon terlebih dahulu, kemudian jika belum ada respon dan sampai tidak membayar 2 kali, maka pegadaian syariah mengirimkan surat peringatan dan apabila tetap tidak ada respon maka pihak pegadaian syariah dapat mendatangi rumah nasabah. Jika nasabah benar-benar tidak mampu untuk membayar kewajibannya maka terdapat kemungkinan bahwa jaminan milik nasabah akan dijual melalui prosedur lelang dengan aturan penjualan jaminan sebagaimana dalam fatwa. Prosedur dalam penjualan barang jaminan yang dilakukan pegadaian syariah yaitu, jika harga jaminan diatas jumlah utang maka kelebihannya dikembalikan ke nasabah. Jika harga jaminan dibawah jumlah utang maka kekurangannya tersebut tetap menjadi tanggung jawab nasabah. Hal ini menunjukkan prosedur lelang yang dilakukan pegadaian syariah telah sesuai dengan fatwa. Apabila terjadi perselisihan antara nasabah dan pihak pegadaian syariah maka diselesaikan dengan jalan musyawarah, namun jika tidak menemukan titik temu maka harus ada keterlibatan dengan Badan Arbitrase Syariah.
2. Fatwa DSN-MUI Nomor:25/DSNMUI/III/2002 tentang Rahn

Pada fatwa ini, beberapa hal yang dibahas yaitu mengenai ketentuan hukum dan ketentuan-ketentuan umum dalam akad rahn. Terkait dengan ketentuan hukum dalam fatwa dijelaskan bahwa pinjaman dengan menggadaikan barang sebagai jaminan hukumnya diperbolehkan. Hal ini juga sejalan dengan prosedur produk Arrum Haji karena nasabah diwajibkan menyertakan jaminan (marhun) berupa emas atau logam mulia.

Selanjutnya yaitu terkait dengan ketentuan-ketentuan umum dalam akad rahn. Ketentuan-ketentuan tersebut diantaranya yaitu: 1) marhun ditahan oleh pihak murtahin sampai akad selesai, 2) marhun tidak boleh dimanfaatkan tanpa seizin rahin, 3) pemeliharaan dan penyimpanan jaminan menjadi tanggung jawab murtahin, rahin hanya wajib membayar biaya mu'nah, 4) besarnya biaya mu'nah tidak boleh ditentukan berdasarkan jumlah pinjaman, 5) ketika nasabah tidak melaksanakan kewajibannya maka murtahin wajib mengingatkan. Namun apabila nasabah tidak lagi mampu melunasi kewajibannya maka LKS diperbolehkan menjual jaminan sebagai pengganti kewajiban nasabah. Peraturan dalam penjualan jaminan yaitu jika harga jaminan diatas utang maka 
kelebihannya dikembalikan ke nasabah. Jika harga jaminan dibawah utang maka kekurangannya tetap menjadi tanggung jawab nasabah.

Keseluruhan prosedur produk Arrum Haji telah memenuhi ketentuanketentuan umum dalam akad rahn. Karena menurut informan jaminan (marhun) disimpan oleh pihak pegadaian syariah dan tidak dimanfaatkan, pihak pegadaian syariah memiliki kewajiban untuk memelihara jaminan dan nasabah hanya diwajibkan membayar biaya mu'nah (biaya pemeliharaan jaminan) yang besarnya tidak ditentukan berdasarkan jumlah maupun jangka waktu pinjaman melainkan ditentukan berdasarkan nilai taksiran jaminan. Pihak pegadaian syariah menentukan biaya mu'nah sebesar $0,95 \%$ dari nilai taksiran jaminan. Kemudian terkait prosedur penjualan marhun, prosedur yang dilakukan pegadaian syariah sudah sesuai dengan ketentuan fatwa DSN-MUI sebagaimana telah dijelaskan dalam analisis fatwa sebelumnya dimana prosedur dimulai ketika nasabah terlambat membayar angsuran. Prosedurnya yaitu pertama pihak pegadaian syariah mengingatkan nasabah lewat telepon dan kedua melalui surat peringatan. Namun apabila nasabah tetap tidak dapat membayar kewajibannya maka terdapat kemungkinan bahwa jaminan akan dijual oleh pihak pegadaian syariah melalui prosedur lelang. Hasil penjualan dari jaminan tersebut digunakan untuk melunasi utang dari nasabah. Aturan dalam penjualan jaminan yaitu jika harga jaminan diatas jumlah utang maka kelebihannya dikembalikan ke nasabah. Jika harga jaminan dibawah jumlah utang maka kekurangannya tersebut tetap menjadi tanggung jawab nasabah.

3. Fatwa DSN-MUI Nomor:29//DSNMUI/VI/2002 tentang Pembiayaan Pengurusan Haji Lembaga Keuangan Syariah

Beberapa hal yang dibahas dalam fatwa ini yaitu mengenai beberapa ketentuan umum dalam proses pembiayaan pengurusan haji oleh Lembaga Keuangan Syariah (LKS). Beberapa ketentuan dalam proses pembiayaan haji diantaranya yaitu: (1) pada dasarnya pembiayaan pengurusan haji diperbolehkan dengan menggunakan prinsip qardh atau utang-piutang. (2) dalam prosesnya, LKS diperbolehkan mengenakan ujrah atau imbal jasa pengurusan. Ketentuan terkait ujrah dalam fatwa yaitu ujrah menggunakan prinsip ijarah dan besarnya tidak boleh ditentukan berdasarkan pembiayaan yang diberikan.

Pada produk Arrum Haji, akad yang digunakan yaitu akad rahn yang timbul karena adanya utang-piutang. Selanjutnya yakni poin mengenai ujrah. Ujrah yang diterima pegadaian syariah 
yaitu berasal dari biaya mu'nah atau biaya pemeliharaan jaminan. Besarnya biaya mu'nah tersebut yaitu $0,95 \%$ dari nilai taksiran jaminan sehingga ujrah dalam produk Arrum Haji telah sesuai dengan ketentuan pada fatwa ini karena tidak ditentukan berdasarkan jumlah pinjaman atau pembiayaan yang diberikan. Sehingga keseluruhan prosedur produk Arrum Haji telah memenuhi ketentuan dalam fatwa ini.

\section{V.}

\section{SIMPULAN}

Produk Arrum Haji merupakan inovasi produk talangan haji yang sesuai dengan prinsip syariah. Produk Arrum Haji dikembangkan oleh Pegadaian Syariah sejak tahun 2016 dan dikembangkan atas dasar adanya larangan mengenai produk dana talangan haji dikarenakan sistem ujrahnya yang tidak sesuai dengan syariah. Tujuan utama dari produk ini adalah untuk membantu masyarakat yang ingin menunaikan ibadah haji namun kesulitan mengumpulkan dana sebesar Rp 25.000.000 yang ditujukan untuk setoran awal biaya ibadah haji sehingga bisa mendapatkan nomor porsi haji. Kesesuaian syariah dari produk Arrum Haji di Pegadaian Syariah Cabang Babakan Surabaya telah sepenuhnya sesuai dengan fatwa DSN-MUI. Seluruh operasional produk Arrum Haji telah memenuhi ketentuan-ketentuan dalam fatwa DSN-MUI yang menjadi landasan yaitu fatwa DSN-MUI Nomor:92/DSN$\mathrm{MUI} / \mathrm{IV} / 2014$ mengenai pembiayaan disertai rahn atau Al-tamwil Al-mautsuq bi
Al-rahn, fatwa DSN-MUI Nomor:25/DSNMUI/III/2002 tentang Rahn, serta fatwa DSN-MUI Nomor:29//DSN-MUI/VI/2002 tentang Pembiayaan Pengurusan Haji Lembaga Kevangan Syariah.

Saran dalam penelitian ini yaitu kepada pihak pegadaian syariah diharapkan dapat memberikan lebih banyak edukasi kepada seluruh staffnya mengenai akad-akad muamalah serta aturan dalam fatwa-fatwa DSN-MUI pada tiap-tiap produk. Sehingga setiap staff pegadaian syariah mampu menunjukkan kepada masyarakat bahwa pegadaian syariah memiliki sistem yang terarah dan tentunya sesuai dengan prinsip syariah. Selain itu, adanya edukasi bagi staf pegadaian syariah tersebut juga diharapkan agar wawasan staf tidak hanya terbatas pada Standar Operasional Prosedur (SOP) yang ada saja sehingga lebih dapat mengenalkan keseluruhan produk yang ditawarkan pegadaian syariah khususnya produk Arrum Haji yang terhitung cukup baru.

\section{DAFTAR PUSTAKA}

Ali, Zainuddin. (2008). Hukum Gadai Syariah. Jakarta: Sinar Grafika

Daud Vicary A dan Keon Chee. (2012). Buku Pintar Kevangan Syariah. Jakarta: Zaman.

Hadi, M. Sholikul. (2003). Pegadaian Syariah. Jakarta: Salemba Diniyah

Huda, Nurul. (2010). Lembaga Keuangan Islam: Tinjauan Teoritis dan Praktis. Jakarta: Prenada Media. 
Luthfina, et al/Jurnal Ekonomi Syariah Teori dan Terapan Vol. 6 No. 12 Desember 2019: 2568-2580; IMPLEMENTASI FATWA DSN-MUI PADA PRODUK ARRUM HAJI DI PEGADAIAN SYARIAH CABANG BABAKAN SURABAYA

Mulazid, A. Sofyan. (2016). Kedudukan Sistem Pegadaian Syariah. Jakarta: Kencana.

Rais, Sasli. (2006). Pegadaian Syariah: Konsep dan Sistem Operasional (Suatu Kajian Kontemporer). Jakarta: Universitas Indonesia

Rozalinda. (2016). Fikih Ekonomi Syariah: Prinsip dan Implementasinya pada
Sektor Keuangan Syariah. Jakarta: Rajawali Press.

Soemitra, Andri. (2009). Bank dan Lembaga Kevangan Syariah. Jakarta: Kencana.

Suhendi, Hendi. (2016). Fiah Muamalah. Jakarta: PT Raja Grafindo Persada.

Yin, R K. (2015). Studi Kasus: Desain dan Metode. Depok: Rajawali Press. 